\title{
Verdian lyric theatre. Hermeneutics of the performance and contemporary challenges
}

\author{
EDITH GEORGIANA ADETU, PhD Student \\ "Transilvania" University Brașov \\ ROMANIA *
}

\begin{abstract}
Engaging the viewer in a dialogue with the opera of Giuseppe Verdi is an approach that involves him spiritually, culturally, morally. You can enter this universe of opera music through several gates. The wide path of science will walk through the portal of stylistics, aesthetics, philosophy or art history. On another road comes the profane, motivated by the love for the beautiful. The opera Nabucco was the first step in the evolution of Italian lyrical theatre - from melodrama to realistic drama characterised by the unity and strength of artistic conception, the energy and simplicity of musical language. Verdi's dramatic sense and affinity for realism propelled him over time into the role of composer- playwright, his name being closely linked to titles such as: Ernani, Luisa Miller, Macbeth, Othello, Falstaff. However, we can note in recent decades the lack or low presence of important titles among Verdian operas in the repertoire of lyrical theatres. Can the contemporary public still receive this composer's authentic message? Can current performers wear the clothes of truthful characters and meet the composer's requirements for the vocal approach? The mission of hermeneutics - this interdisciplinary science - is to discover, as far as possible, the mechanisms of the interpretation of a social phenomenon (as the opera of Giuseppe Verdi has been repeatedly perceived), and its reminiscences in contemporary society.
\end{abstract}

Keywords: Verdi, hermeneutics, interpretation, performance.

\section{Introduction}

Often, when we try to deal with the problem of the interpretation of music - including here the evolution of interpretation - we realise that a series of paradoxes appear, seemingly arising from the ineffable. When we discuss the style approached in interpretation, it is interesting to compare the version that is offered to us today in the performance hall or through the media, with versions of interpretations considered optimal in a not very distant artistic past. However, there is the risk of us following in this area of interpretation a continuous reference to an interpretive tradition, running the risk of falling into the trap of unwanted passéisme. Viewed from another point of view - the style in interpretation - it must be adapted to contemporary requirements, as long as there is no danger of altering the music, the artistic act and its authenticity.

\footnotetext{
*adetuedith@gmail.com
} 
Verdian lyric theatre is a legacy of all-time lyrical art. Perpetuating such a performance, as complex as it is profound, is primarily about educating - both vocally and culturally - interpreters who can carry on this legacy. On the other hand, the perpetuation of an authentic performance is also about the degree of receptivity of the audience. We see that the contemporary public reacts to different stimuli compared to the audience of past decades. The trap of modern society tends to encompass the world of lyrical theatre as well, so that the essence of the operas (vocal peculiarities, quality of librettos, presentation of a certain era) is reflected in a superficial way, so much so that certain titles disappear from the posters of the performance institutions. Verdi is one of the eloquent examples of this phenomenon; most of his operas are not represented on stage. The titles of Verdian operas represented in lyrical theatres around the world are limited to an infinitesimal part of his work. We consider that these observations are closely related to the evolution of the interpretive artistic act in general, and offer a vision of the society in which art must evolve, or at least manifest itself authentically.

\section{Hermeneutics: science and art of interpretation}

Hermeneutics, this practice of interpretation, appeared very early in the history of civilizations. The Antiquity's great cultures generally had their share of the sacred literature that had to be interpreted within the clergy and royal houses. Thus, hermeneutics was practiced by ancient humans long before it represented a branch of philosophy, being considered a science in its own right. In late antiquity, Greeks, Jews and Christians read and interpreted their fundamental texts, many of which were represented by religious writings. According to historical evidence and testimonies, hermeneutic sciences developed in accordance with the evolution of society. "Plato approaches a hermeneutics of symbols, Aristotle leaves as a legacy a treatise of interpretation that deepens the understanding of holy books, and later, in the Middle Ages and Renaissance, the patristic theology and the art of interpreting philological texts stand out as branches of hermeneutic sciences" (Coroiu, 2018, p. 34).

The full development of hermeneutics as a methodology of interpretation happened several centuries later, during the Renaissance period. This development was triggered by the increased need for hermeneutic practice, which turned the once-pure operation into a self-aware procedure. This increased need for practice was catalysed by two prominent historical phenomena: Protestant reform and the Renaissance's fascination with classical Greek and Roman texts. The Protestant Reform gave rise to a whole process of debate about the Christian's relationship with the sacred scriptures. While the Catholic Church reaffirmed, during the Council of Trent, its ancient position of being ITS own authority, Protestants insisted on the principles of visibility - 
the need for an understanding of the discernment of the interpreter and the selfsufficiency of the Sacred Scriptures. The Renaissance's fascination with classical Greek and Roman texts, as the second catalyst, has already generated a whole arsenal of interpretive methodologies, collectively known as Ars Critica, useful in establishing the authenticity of the texts, as well as in reconstituting the most original and correct version of the text. Along with this purely humanistic concern, Renaissance jurists also struggled to specifically reinterpret Roman law (e.g. the Justinian Code).

Therefore, the hermeneutic methodology of interpretation did not fully develop during the Renaissance, but proliferated in a collection of contradictory, incoherent and confusing systems. Set in a crucible of intense philosophical analysis and subsequent theorizing, Hermeneutics emerged as a stronger system, not only for religion and humanism, but also for the evergrowing social sciences. Carrying forward the Hermeneutics from the world of religious and humanistic textuality in the sphere of the action, behaviour and culture of the social sciences was facilitated by the extension of the meaning of textuality itself. What has been understood traditionally as something that only refers to things that are or can be written has been stretched to cover almost anything related to man and culture. Today, not only documents, literary texts and scriptures can be subjected to hermeneutic approach, but also symbols, rituals, cultural, artistic phenomena, etc. Friedrich Daniel Ernst Schleiermacher (1768-1834), German Protestant theologian and philologist, was the one who initiated the focus of philosophy on the problems of interpretation and addressed the need for a systematic, unified method of Hermeneutics. He defines the Hermeneutics as: "the art of understanding correctly the discourse of another person" (Schleiermacher, 1998, p. 20).

\subsection{Hermeneutics of opera performance}

In the modern era, philosophers such as Schleiermacher, Dilthey, Heidegger, Gadamer, Habermas, are recognised for their contributions to the development of hermeneutic sciences. In 2015, the famous Romanian opera singer, Ion Piso, published the book Crisis of Opera? A Study of Musical Hermeneutics, making a special invitation to both listeners and opera singers, to better understand the opera performance and its role in contemporary society. Hermeneutics and music - two horizons of human spirituality, so comprehensive, with thrilling depths and heights. These horizons, side by side, are the subject of relentless discussions. In essence, the hermeneutic approach contributes to the understanding of this social phenomenon materialised in the form of opera performance.

The contemporary man of art (the performer, the creator) is confronted today with questions concerning the ontological foundations of the human condition. What are the individual's current relationships with society? What is 
the status of contemporary lyrical theatre and what is the public's approach to the traditions of the genre? What new configurations and consequences will the momentum and expansion of contemporary knowledge have? What are the social consequences of the explosion of science and technology in recent decades? The wording of these questions is random, and yet it is entirely aimed at the destiny of the opera performance, subject to the changes imposed by modernity. However, to me is seems important that today, as a lyric artist, musician, conductor, etc., you cannot escape giving, or at least suggesting answers, to decide attitudes in the face of these questions. The turmoil of history marks great social and political earthquakes throughout the $20^{\text {th }}$ century (a good part of the world's population has gone through two great world conflagrations, and has known the struggle for humanism and humanity). In these circumstances, people of art and culture are forced to give more and more space to political thought, with art, music and beauty largely losing their meaning. The $21^{\text {st }}$ century brings with it new paradigms, new human pursuits in the social-historical field, in which art can provide an answer, a suggestion, an attitude - with its specific means - to human problems. So that "cultural acquisitions of previous eras produce mutations in reception." (Gaspar, 2000, p. 96)

Referring strictly to the status of the lyrical theatre, i.e. the Verdian lyrical theatre, this represents a happy case, frequently appearing in the seasons of the institutions of profile. The issues of Verdi's opera and the need to use hermeneutic approach is closely related to the understanding of human spirituality described in his opera. Specifically, we refer to the interpretation of Verdian opera - both from the perspective of the performer and from the perspective of the audience - which cannot be foreign to the above mentioned horizon. Carmen Cozma describes this approach to hermeneutic phenomenology, with great spirit: "We are interested, as a priority, in phenomenology as a method of the 'eidetic description' of art, here: of music, of the release of a certain essence, of a self from the art experience in the plurality of relations with musical opera, activated at the level of the subjectreceiver / auditor / listener; respectively, the perceptive subject of soundartistic creation; the one who, following direct contact with a (musical) 'text', is discovered as 'another' than the one before such an experience." (Cozma, 2013, p. 46)

\section{Gius eppe Verdi's opera and the social attribute}

Researching the long career of the great Italian composer, who debuts with the opera Oberto - 1839 and ends with the opera Falstaff - 1893, we can consider that it is divided into three stages of creation: Oberto (1839) - Battle of Legnano (1849), the stage at which the political-revolutionary influences take precedence; Luisa Miller (1849) - The Force of Destiny (1862), during 
which Verdi consolidated a compositional style influenced by the literature of the time (V. Hugo, Al. Dumas); Macbeth (1865) - Falstaff (1893), perhaps the most complex period of creation, in which he completes his calling as a playwright - it is also the transition period to realistic musical drama.

As for the social attribute of Verdian opera, we will consider the first stage of creation, which reflects Giuseppe Verdi's social impact. Musicologist Alice Mavrodin supports these ideas by saying: "Verdi had an exceptional ability to integrate psychologically into the spirit of the era, to spontaneously assimilate those invisible currents that feed the spiritual life of a great community and which, for him, turn into creative impulse. However, at the time, the mentioned currents were of patriotic-heroic hue, by no means humorous-burlesque" (Mavrodin, 1970, 35). Thus, the operas that reflect the spirit of the era are in particular: Nabucco: La Scala, Milan - 9 March 1842; Lombards in the first Crusade: La Scala, Milan - 11 February 1843; Ernani (after Hugo): La Fenice, Venice - 9 March 1844; The Two Foscari (after Byron): Argentina, Rome - November 3, 1844; Joan of Arc (after Schiller): La Scala, Milan - 15 February 1845; Alzira: San Carlo, Naples - 12 August 1845; Attila: La Fenice, Venice - 17 March 1846; Macbeth (after Shakespeare): La Pergola, Florence - 14 March 1847; Thieves (after Schiller): Royal Theatre, London - 22 July 1847; Jerusalem (an adaptation of the Lombards): Grand Opera, Paris - 26 November 1847; Corsair (after Byron): Triest - 25 October 1848; Battle of Legnano: Argentina, Rome - 27 January 1849. In the context of the above, Alice Mavrodin recounts: "as for these musically reflected characteristics, they could be defined in two words: simplicity and dynamism. (...) the simplicity to which we refer lies in the plane of affective feelings, which the music suggests, a layout dominant by some fundamental attitudes: energetic affirmation of personality (often in protest form), its opposite, i.e. imploration or fear, seldom dreaming and that's about it. And the atmosphere is bright-exuberant at times, other times it is sombre and violent, sometimes even mysterious and, here and there, lyrical" (Mavrodin, 1970, 41). This is how we could describe the operas by which Giuseppe Verdi stands out in the first period of creation: a personal music, alive, acclaimed by a society on the decline.

\subsection{Verdian lyric theatre and the vocation of actuality}

What is in Verdi's theatre, that something that attracts audiences? An eloquent answer would include the following statements: Verdi's passionate music striving more often to stir and excite the audience, to arouse real feelings, compared to Rossini, Bellini or Donizetti, who almost always strive to delight it. Verdi's ability to attract audiences to participate emotionally in the drama on stage has been amplified during his creation, vesting the characters of his operas with human traits, truthful, so that the audience empathizes with the 
protagonists, be they good or bad. Think, for example, about how Verdi makes this transition, from Nabucco to Macbeth, at the end of Rigoletto where he manages to move the audience to empathize with a character whose morality is in question. We reinforce the above with the following statements: "In the way of his searches for customization, gradual distancing in relation to his predecessors, the composer grants two main dimensions to the development of musical dramaturgy: on the one hand, the activation, sometimes picturesque, other times declamatory, of choral ensembles, which, it is understood, justifies the adaptation of the subject to Verdian time; on the other hand, the continuation of the characterological definitions of the characters" (Constantinescu, 2009, p. 24).

Finally, and perhaps most appealing to the public, is his gift for song. The Verdian melody creates extraordinary states. Even in places where the text has become stingy and no longer reveals meaning, the song alone can do it. Thus, when the Count of the Troubadour sings about his love for Leonora, even those who cannot understand the words understand the emotion. In addition, the song creates a communion between the stage and the audience, merging a thousand individuals into a single receptive unit. And few are those - if any - who could compete with Verdi's ease of summarizing a dramatic situation with a short, penetrating melodic phrase, such as the cry of Aida, Numi, pietà or the cry of Desdemona, Salce, Salce. The words of Ion Piso are relevant, referring to the effectiveness of the dramatic accent: "Thanks to this great Verdian innovation, the interpretation will be felt with a great intensity of musical participation, with all its valences, without stifling the typical Italian melodism" (Piso, 2015, p. 17). However, we note in recent decades the representation of the same opera titles in the Verdian repertoire, both in Romania and in the major European opera theatres. One of the great contemporary challenges for the future of Verdian opera consists in the theatres' gradual surrender of the operas considered as more dramatic in terms of their meaning. And yet, we cannot help but wonder: under these conditions, will Verdi still be able to dominate the operatic repertoire as it does today? The actuality of his opera is a certainty at present, but its future depends on a cumulation of factors: the right performers, the direction to support the ethos of the operas, the musical direction and last but not least, an audience ready to receive Verdi's music, in its authenticity.

\subsection{Stylistic elements in the opera of Giuseppe Verdi}

In connection with the Verdian compositional style found in opera music, many descriptions can be launched, but its most important characteristics are the melodic component - which metamorphoses at each stage of creation - and the vocality component, through which Verdi performs stylistic syntheses. We find these summaries especially in the writing of the cabalettas, which, starting 
with the Nabucco opera, open an evolutionary path in terms of the structure of the vocal discourse. We also note new technical and interpretive requirements in the approach of soloist scores, which require the development of a solid singing technique. Valentina Sandu-Dediu offers some coordinates of style determination, eloquent in the context of this research: "The pragmatic side of thinking about style takes into account the expectations of the audience or the types of 'patronage' that subsidize the composition [...], visible in preference for certain genres or in stylistic conditioning of a certain ethos" (Sandu-Dediu, 2013, p. 40). These statements describe the compositional mentality and Verdian style of the creative period 1839-1849, a period dominated by patriotic momentum (reflected in Nabucco and Lombards). Thus, the auditor's expectations of the abovementioned nationalist discourse and ethos are aggregated in the first Verdian operas. Regarding the cabaletta and the stylistic meanings of this period, we can observe a subtle detachment from the old principles of the Italian melodrama of the early $19^{\text {th }}$ century, leaving to appear a descriptive character from it, thus reinforcing new vocal and character typologies (Abigaile, Zaccaria, Nabucco-Nabucco).

Starting with the second half of the $19^{\text {th }}$ century we can notice a new stylistic direction (Stiffelio, Rigoletto, Troubadour, Traviata), in which we notice the detail of some stylistic parameters - the melody and rhythm enriching in particular the vocal discourse. Valetina Sandu-Dediu presents an interesting perspective of style as a phenomenon, having the following stylistic parameters: "Style and melody: the ethos of themes generates a piece, the melody is guided by form, supported by harmony, articulated by writing and rhythm. Melodic styles may be regular or irregular, flowing or spasmodic, expositional or developing, conjunct or disjunct, vocal or instrumental, structural or ornamental. [...] All these aspects of musical language come together to clarify the expressive purposes of the composer" (Sandu-Dediu, 2013, p. 31). Regarding the ethos of Verdian opera, we consider it widely represented through the music-dramaturgy relationship. Regarding the evolution of vocality in Verdian drama, the words of the conductor Cristian Sandu are relevant: "From the perspective of vocality, the extreme and, on the contrary, hidden and original areas of the voice are intensely explored in timbre and dynamics, which can capture the finest psychological nuances (in Macbeth and Othello), Verdi giving up the rhythmic-melodic patterns of his predecessors (which is visible especially in cadences). Consequently, the voice receives a quasi-orchestral resonance, while the orchestra will acquire the suppleness, richness and interiority of the singing. A language that tends to form in direct correspondence with the intimate needs of the character of the drama, a language not only different from that of the melodrama but sometimes quite the opposite of it" (Sandu, 2018, p. 12). 


\subsection{Verdian Lyric Theatre: Stylistic Coordinates in the Vocal Approach}

The approach of the Verdian repertoire is closely related to the acquisition of technical skills, traditional to the Italian school of singing. At the beginning of the 19th century, new vocal typologies emerged: the dramatic soprano of agility (or the dramatic coloratura soprano), the dramatic mezzosoprano of agility and the dramatic baritone. The vocal typology of the dramatic coloratura soprano begins to assert itself in the repertoire of Bellini (Puritans, Norma, The Pirate) and Donizetti (Maria Stuarda, Maria di Rohan, Gemma di Vergy), of the dramatic mezzo-soprano in the repertoire of Rossini (Semiramide) and Donizetti (The Favourite). In contrast, the dramatic baritone becomes a constant presence among the roles of the three composers. In this context, the term dramatic does not refer to the actual action of the opera, but to the type of writing attributed to the voices (the extent of the vocal ambitus, large interval leaps, dynamic contrasts in the acute register of the voice, sustained legato). A teacher in the art of singing, Ana Rusu states the following: "The tradition of the Italian school was linked to finesse and elasticity in singing and in no way to strength or tension, and the aesthetic effect of acute sounds was precisely in the sense by tension. Thus, the high tones were perfectly framed in the melodic line by the performers, without emphasising them from the other sounds" (Rusu, 2006, p. 48). Returning to the aforementioned vocal typologies, they will be fully affirmed in the creation of Giuseppe Verdi, who starting with the opera Nabucco will make a transition between the traditional Bel canto style to a more dramatic style, which can be recognised as dramatic Bel canto. One of the great conquests of this style was the development of the cabaletta, managing to turn it into a spectacular moment of vocal virtuosity. We also recall the importance given to the spoken voice in the Italian school of singing, the dictum it is sung as spoken being maintained. A former doctor at the Metropolitan Opera and a renowned phoniatrician in New York in the first half of the 20th century, Pasqual Mario Marafioti states in connection with the vocal emission specific to the Italian repertoire: "The two forms of voice, speech and singing, being the same physical element, are so connected that the neglect of one means the abolition of the production and beauty of the other" (Marafioti, 1958, p. 165).

In choosing and strengthening the repertoire a very large influence is exercised by native data. Of course, they need to be accompanied by a rigorous technical training, whereby the interpreter can increase his/her repertoire range along with physiological and psychological maturing. I wanted to talk about this native data because it is an essential condition in addressing the Verdian repertoire. The most important native data of the Verdian vocality particularity are: timbre and volume. Most Verdian roles require dark voices in timbrality, but possessing ample volume and ambitus. Thus, we can also speak of a personal style of interpretation, by which the leading performers have remained 
in the history of opera music (Caruso, Corelli, Nilsson, Callas, Tebaldi, Price considered Verdian performers). Another component of personal vocal style in the context of Verdi's opera is the training of mind and memory. The dramaturgical contexts of the operas are complex and in order to be able to faithfully play the musical score the performer must become a true character. On the other hand, the dimensions of the roles are extensive, requiring a rigorous training of memory as well as physical support. In summarizing the above, we can say that a good performer of Verdi's music will be distinguished by: the correct playing of the dramatic message, based on a good performance of vocal virtuosity. Salvatore Fucito, Caruso's pianist and vocal coach, says: "To be considered an artist, the singer must acquire the style of the composer he performs so as to reproduce the particular character of the work he is performing. His singing must be true to his spirit, but his spirit must reflect the feelings of the composer and the work" (Fucito \& Barnet, 1922, p. 209). In light of all the above, we consider that the Verdian lyrical theatre is a real school of singing, its perpetuation being a necessity.

However, we are currently witnessing a crisis of voices that are tailored for the Verdian repertoire - another aspect of the contemporary challenges on which we stand through this research. An interesting and objective point of view is offered by Mihaela-Silvia Rosca, in the article Theses and antithesis in contemporary opera theatre: "The bicentennial celebrations of Giuseppe Verdi and Richard Wagner have brought back several questions to the public space, but one of them, an important one, regarding the ability of the operatic world to find appropriate interpreters for its own works, seems to have remained fundamentally unresolved. Specifically, I am referring to the perception that there is a crisis of those types of voices that formed at the time when the two composers were at the height of their creation and who continued to dominate the lyrical scene long after their death: sopranos and spinto tenors, dramatic sopranos and mezzo-sopranos, Verdian baritones, Heldentenors, bass-baritones and Wagnerian basses" (Rosca, 2016, p. 324). On the question "can hermeneutics intervene in the choice of opera interpreters suitable for the Verdian repertoire?" an affirmative answer hovers, followed by the explanation: once the specific requirements are understood, rendered concretely through the score, the choice of interpreters is an easy step. The big problem for the interpreters of such a repertoire is that of vocal technique, which involves the exclusive study of roles of endurance and virtuosity. However, the results of such a study are obtained over a long time - different from one voice to another.

\section{The Audience: the fundamental dimension of lyrical theatre}

Participation is the product of a state of congeniality, of affective concordance between the audience and the performance. Participation 
represents more deeply and completely the idea of receiving the union between the public and the scenic image, because it suggests more prominently the relationship of communion, including value appreciation. In other words: "the opinion of the music lovers is not at all negligible, because since its inception the opera performance was intended for the public, the public being the rightful beneficiary of the act of creation" (Rosca, 2016, p. 323). The notion of participation encloses in itself the entire history of the art of the performance. It expresses in a synthetic manner the permanence of the coexistence between lyrical theatre and the public. "For these sensitive forms and tones appear not only in art for themselves and for the sake of their immediate appearance, but for the purpose of offering, in this appearance of them, satisfaction to superior spiritual interests, for they have the power to awaken - from the depths of consciousness - an agreement and an echo in our spirit. In this way, the sensitive is spiritualised in art, because in it the spiritual appears as sensitised." (Hegel, 1966, p. 45) The audience represents a form of manifestation in the field of art, especially with regard to lyrical theatre, this syncretic existence. It is the life of the opera, the succession of mutual influences depending on this life. As for Verdian lyrical theatre, all of Verdi's operas are about people without deriving the world through myth, in a surreal way, each opera is anchored in a human experience. With greater or lesser success, Verdi portrays his peers, and for such stories, human stories, there will always be an audience. After all, the quality of the artistic act and at the same time the shaping of an audience able to recognise and appreciate that quality objectively takes precedence. The contribution of hermeneutics in this context concerns "the importance of phenomenological suffrage in the effort to find out the essenceleidos, the invariable structure of life, in relation to artistic creation; in this case: artistic-musical creation" (Cozma, 2013, p. 47).

\section{Conclusions}

This study represents a brief analysis of the usefulness of hermeneutics as a way of deepening Giuseppe Verdi's creation, emphasising the complexity of the mechanism of reception of Verdian lyrical theatre. In the act of artistic, musical communication, there is a transmission of information of certain specificity, from the creator to the public, information contained in the codified message of the opera. In this relationship, the audience is subject to a multiple conditioning, namely: value - provided by the qualitative level of the work of art, social - involving the formative and psychological means - in which the whole cognitive, affective system of the personality of the receiver is engaged. The hermeneutic approach is joined by the other disciplines that facilitate a good understanding of Verdi's opera (stylistics, aesthetics, music history, the study of vocal technique, etc.), in order to achieve a genuine artistic act and at the same time to receive such an act. 


\section{References}

Constantinescu, G. (2009). Giuseppe Verdi. București: Editura Didactică și Pedagogică.

Coroiu, P.M. (2018). Semantică și hermeneutică muzicală: curs [Semantics and musical hermeneutics: Course]. Craiova: Editura Universitaria.

Cozma, C. (2013). Repere într-o hermeneutică a muzicii [Highlights in a Hermeneutics of Music]. Artă și Educație Artistică [Art and Artistic Education], 21, 45-51. Bălți: Biblioteca Ştiinţifică a Universităţ̧ii de Stat „Alecu Russo”.

Fucito, S. \& Barnet, B. (1922). Caruso and the art of singing. New York: Frederik A. Stokes Company.

Gaspar, V. (2000). Repere spațiale și semantice în receptarea muzicală [Space and semantic landmarks in musical reception]. București: Editura Muzicală.

Hegel, F. (1966). Prelegeri de estetică [Aesthetic Lectures], I (Translation by D.D. Rosca). București: Editura Academiei R.S.R.

Marafioti, M. (1958). Caruso's Method of Voice Production - The Scientific Culture of Voice. Austin, Texas: D. Appleton and Company.

Mavrodin, A. (1970). Verdi. București: Editura Muzicală a Uniunii Compozitorilor.

Piso, I. (2015). Criza operei? Studiu de hermeneutică muzicală [The opera crisis? Study of musical hermeneutics]. București: Editura Eikon.

Rosca M.S. (2017). Teze și antiteze în teatrul de operă contemporan [Theses and antithesis in contemporary opera theatre]. Qvastiones Romanicae, VI/1, 323-328. Retrieved from: https://ciccre.uvt.ro/ro/qvaestiones-romanicae/articole/teze-antitezeteatrul-opera-contemporan

Rusu, A. (2006). Tehnica și virtuozitatea solistică - condiții necesare interpretării vocale [The technique and virtuosity of the soloist - conditions necessary for vocal interpretation]. Cluj-Napoca: Editura MediaMusica.

Sandu, C. (2018). Stilemele verismului în evoluția operei moderne [The stiles of verism in the evolution of modern opera]. Cluj-Napoca: Editura MediaMusica.

Sandu-Dediu, V. (2013). Alegeri, atitudini, afecte [Choices, attitudes, affections]. București: Editura Didactică și Pedagogică.

Schleiermacher, F. (1998). Hermeneutics and criticism and other writings (Translated and edited by Andrew Bowie). United Kingdom: Cambridge University Press. 